NASA/TM-2004-213202

ARL-TR-3251
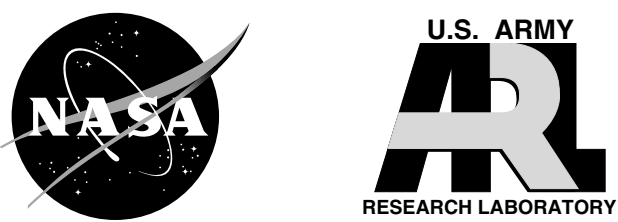

\title{
Sensor Needs for Control and Health Management of Intelligent Aircraft Engines
}

Donald L. Simon

U.S. Army Research Laboratory, Glenn Research Center, Cleveland, Ohio

Sanjay Gang, Gary W. Hunter, and Ten-Huei Guo

Glenn Research Center, Cleveland, Ohio

Kenneth J. Semega

Wright-Patterson Air Force Base, Dayton, Ohio 
Since its founding, NASA has been dedicated to the advancement of aeronautics and space science. The NASA Scientific and Technical Information (STI) Program Office plays a key part in helping NASA maintain this important role.

The NASA STI Program Office is operated by Langley Research Center, the Lead Center for NASA's scientific and technical information. The NASA STI Program Office provides access to the NASA STI Database, the largest collection of aeronautical and space science STI in the world. The Program Office is also NASA's institutional mechanism for disseminating the results of its research and development activities. These results are published by NASA in the NASA STI Report Series, which includes the following report types:

- $\quad$ TECHNICAL PUBLICATION. Reports of completed research or a major significant phase of research that present the results of NASA programs and include extensive data or theoretical analysis. Includes compilations of significant scientific and technical data and information deemed to be of continuing reference value. NASA's counterpart of peerreviewed formal professional papers but has less stringent limitations on manuscript length and extent of graphic presentations.

- TECHNICAL MEMORANDUM. Scientific and technical findings that are preliminary or of specialized interest, e.g., quick release reports, working papers, and bibliographies that contain minimal annotation. Does not contain extensive analysis.

- CONTRACTOR REPORT. Scientific and technical findings by NASA-sponsored contractors and grantees.
- CONFERENCE PUBLICATION. Collected papers from scientific and technical conferences, symposia, seminars, or other meetings sponsored or cosponsored by NASA.

- SPECIAL PUBLICATION. Scientific, technical, or historical information from NASA programs, projects, and missions, often concerned with subjects having substantial public interest.

- TECHNICAL TRANSLATION. Englishlanguage translations of foreign scientific and technical material pertinent to NASA's mission.

Specialized services that complement the STI Program Office's diverse offerings include creating custom thesauri, building customized databases, organizing and publishing research results ... even providing videos.

For more information about the NASA STI Program Office, see the following:

- Access the NASA STI Program Home Page at http://www.sti.nasa.gov

- E-mail your question via the Internet to help@sti.nasa.gov

- Fax your question to the NASA Access Help Desk at 301-621-0134

- Telephone the NASA Access Help Desk at 301-621-0390

- Write to:

NASA Access Help Desk

NASA Center for AeroSpace Information 7121 Standard Drive

Hanover, MD 21076 
NASA/TM-2004-213202

ARL-TR-3251
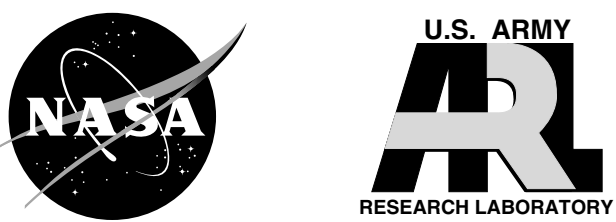

\section{Sensor Needs for Control and Health Management of Intelligent Aircraft Engines}

Donald L. Simon

U.S. Army Research Laboratory, Glenn Research Center, Cleveland, Ohio

Sanjay Gang, Gary W. Hunter, and Ten-Huei Guo

Glenn Research Center, Cleveland, Ohio

Kenneth J. Semega

Wright-Patterson Air Force Base, Dayton, Ohio

Prepared for the

Turbo Expo 2004

sponsored by the American Society of Mechanical Engineers

Vienna, Austria, June 14-17, 2004

National Aeronautics and

Space Administration

Glenn Research Center 


\section{Acknowledgments}

The authors wish to graciously acknowledge the following individuals who contributed information towards the writing of this paper: Al Behbahani, Clarence Chang, Dennis Culley, John DeLaat, Paula Dempsey, Gustave Fralik, Andrew Gyekenyesi, Kevin Melcher, and Carolyn Mercer.

Trade names or manufacturers' names are used in this report for identification only. This usage does not constitute an official endorsement, either expressed or implied, by the National Aeronautics and Space Administration.

Available from

NASA Center for Aerospace Information 7121 Standard Drive

Hanover, MD 21076
National Technical Information Service 5285 Port Royal Road Springfield, VA 22100 


\section{SENSOR NEEDS FOR CONTROL AND HEALTH MANAGEMENT OF INTELLIGENT AIRCRAFT ENGINES}

\author{
Donald L. Simon \\ U.S. Army Research Laboratory \\ Glenn Research Center \\ Cleveland, Ohio
}

\author{
Sanjay Garg \\ Gary W. Hunter \\ Ten-Huei Guo \\ National Aeronautics and Space Administration \\ Glenn Research Center \\ Cleveland, Ohio
}

\author{
Kenneth J. Semega \\ Wright-Patterson Air Force Base \\ Dayton, Ohio
}

\section{ABSTRACT}

NASA and the U.S. Department of Defense are conducting programs which support the future vision of "intelligent" aircraft engines for enhancing the affordability, performance, operability, safety, and reliability of aircraft propulsion systems. Intelligent engines will have advanced control and health management capabilities enabling these engines to be self-diagnostic, self-prognostic, and adaptive to optimize performance based upon the current condition of the engine or the current mission of the vehicle. Sensors are a critical technology necessary to enable the intelligent engine vision as they are relied upon to accurately collect the data required for engine control and health management.

This paper reviews the anticipated sensor requirements to support the future vision of intelligent engines from a control and health management perspective. Propulsion control and health management technologies are discussed in the broad areas of active component controls, propulsion health management and distributed controls. In each of these three areas individual technologies will be described, input parameters necessary for control feedback or health management will be discussed, and sensor performance specifications for measuring these parameters will be summarized.

\section{INTRODUCTION}

NASA and the U.S. Department of Defense are pursuing revolutionary technology advances to achieve the realization of intelligent aircraft engines, which will be self-diagnostic, selfprognostic, self-optimizing, and mission adaptable. These engines will require advanced Propulsion Control and Health Management (PCHM) [1] capabilities including sensors, diagnostics and prognostics, adaptive/active controls, and integrated controls and diagnostics. PCHM is a technology investment that will directly support the NASA goal to enable a safer, more secure, more efficient, and environmentally friendly air transportation system [2]. The objectives of NASA include: 1) decrease the aircraft fatal accident rate and the vulnerability of the air transportation system to threats, and mitigate the consequences of accidents and hostile acts; 2) protect local and global environmental quality by reducing aircraft noise and emissions; and 3) enable more people and goods to travel faster and farther, with fewer delays.

PCHM technology also plays a prominent role in the Department of Defense Versatile Affordable Advanced Turbine Engine (VAATE) Program which is focused on achieving a 10 times improvement in the combined areas of engine capability and affordability [3]. The VAATE program balances the emphasis on capability (performance, operability, survivability and robustness), and affordability (development, production and maintenance costs). The VAATE Intelligent Engine focus area spans diverse technologies, including active control and engine health management, to achieve a self-optimizing, selfdiagnosing, mission-adaptable propulsion system.

Sensing technology is the foundation upon which a PCHM system is based as it is relied upon to accurately collect the data required for engine control and health management. Today's aircraft propulsion systems are typically equipped with a suite of control sensors (temperatures, pressures, rotor speeds, etc.), the outputs of which are used as inputs by the engine control logic. Additionally, engines are typically equipped with various sensors for health monitoring purposes and cockpit displays. These can include lubrication and fuel system sensors (pressure and flow), accelerometers, and gas-path instrumentation for performance monitoring purposes. 


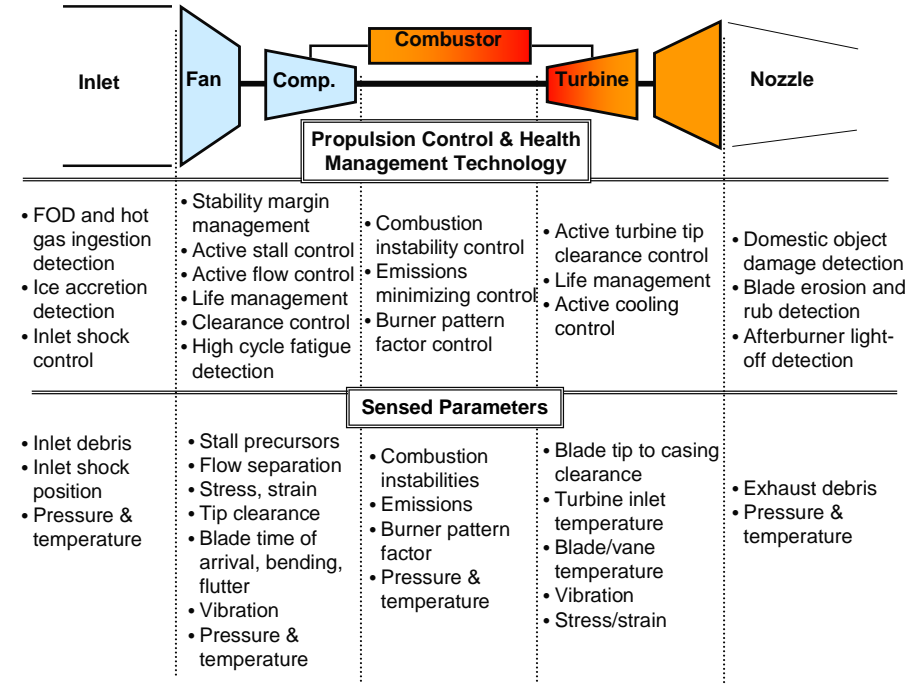

\section{Figure 1. PCHM Technologies and Associated Sensed Parameters}

Current research efforts are making critical advances in sensing technology such as enhancements in the areas of weight, size, cost, accuracy, reliability, and robustness. New sensors are being developed to enable the measurement of previously un-measurable parameters critical for assessing the overall health of the propulsion system. Advances in sensing technology, including smart sensors, and the insertion of this technology into next generation aircraft propulsion systems will enable the transition from manual inspection practices to automated assessments, and the transition from conventional control logic to advanced adaptive/reconfigurable control logic, making the vision of intelligent aircraft engines a reality.

This paper will review the anticipated sensing needs to support future intelligent aircraft engines from a control and health management system perspective. The PCHM enabling technologies for "Intelligent Engines" can be organized into three broad categories - active component control, advanced health management, and distributed fault tolerant control. This paper will discuss the sensor needs to support intelligent aircraft engines in the context of these three areas. Some of the PCHM technologies to be discussed, along with their associated sensing needs and engine location, are introduced in Fig. 1.

It should be noted that this paper is not meant to be allencompassing. It is acknowledged that each one of these research areas and associated sensor requirements can be discussed in much more detail than available in this format. Rather, this review is representative of the issues regarding sensor technology in these PCHM areas. As such, it is meant to be an initial guide for sensor activities based on the present state-of-the-art understanding rather than a final "how-to" manual. The application of sensor technology in general needs to be tailored for the given application environment, the engine system, and the objectives of the specific PCHM strategy.

\section{ACTIVE CONTROL TECHNOLOGIES AND SENSOR NEEDS}

The traditional aircraft propulsion control system objective has been that of providing the desired thrust response to pilot power lever angle commands while ensuring that the specified safety, operability, and life margins are maintained. In the past, engine components such as combustors, fans, compressors, inlets, nozzles, etc. have been designed for optimum component performance within some overall system constraints. The control design problem has been to transition the operating point of the engine from one point to another in the most expedient manner without compromising any of the limit margins. With the advancements in information technologies, the component designers are beginning to realize the potential of including active control into their component designs to help them meet more stringent design requirements and the need for affordable and environmentally friendly propulsion systems.

For illustration purposes, Fig. 2 shows a simplified diagram of the active control process consisting of the engine, sensors, a control unit, and actuators. Engine sensor feedback measurements are sampled at a specified interval and fed as inputs into the control unit where they typically undergo signal processing and are input into the associated control logic. Control generated commands are then fed out of the control unit to the actuators. Efforts are ongoing to incorporate active control capabilities into inlet, compressor, combustor, and turbine components. Each of these applications has unique sensing, processing, and actuation needs, but in general follow the generic active controls process shown in Fig. 2. These four active control areas are further discussed below with an emphasis on sensing needs.

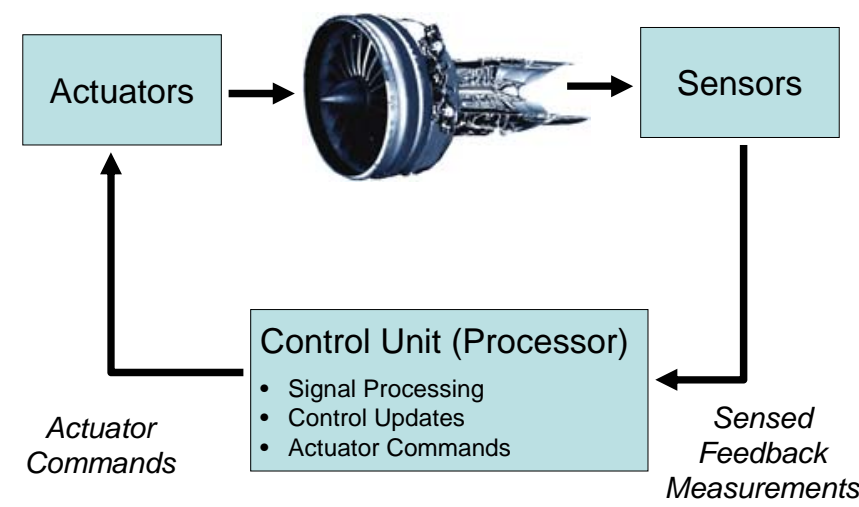

Figure 2. Active Control Process

\section{Active Inlet Control}

For supersonic and hypersonic vehicle applications in the Mach range from 2 to 4, mixed-compression inlets are the most efficient means of transitioning the flow to subsonic speeds for turbine engine operation. Mixed-compression inlets operate with an internal shock structure that is terminated by a normal shock (i.e., flow discontinuity that transitions the airflow from supersonic to subsonic) just downstream of the inlet throat. The safe and efficient operation of these inlets requires that the 
location of the terminal shock be maintained downstream, but very near, the aerodynamic throat (i.e., minimum area). If the shock moves forward of the throat, it becomes unstable and can be expelled from the inlet resulting in a phenomena known as inlet "unstart". With the shock outside the inlet, much of the flow is spilled around the inlet greatly reducing the thrust and increasing drag. Since the inlet unstart phenomena happens very quickly, the large change in moments tends to produce violent motions in the vehicle.

The active inlet controls program was previously conducted in direct support of the NASA High Speed Research (HSR) program, which was developing technologies for a future commercially and environmentally viable supersonic civil transport aircraft. The objective of active inlet control is to develop and validate dynamic models and advanced multivariable control systems for supersonic mixedcompression inlets. The control system needs to be designed to include inlet unstart prevention, automatic restart, distortion minimization and inlet/engine integrated control.

Some of the challenges in implementing active inlet control are determining the best effectors for controlling the shock position, developing accurate models of inlet operation, and developing flight quality sensors for measuring the location of the terminal shock for feedback control purposes. Environmental conditions in the inlet are extreme (thermally), and are significantly affected by Mach number and design geometries. There are several sensor options for measuring shock position including, but not limited to, pressure sensor arrays and optical probes [4]. A review of pressure sensor requirements for inlet control in current and future hypersonic vehicles was performed in reference [5]. The inlet shock position pressure sensing requirements for the SR-71 aircraft [5] are summarized in Table 1 for example purposes.

\section{Active Compressor Control}

Several active control approaches have been investigated to achieve enhanced fan/compressor efficiency. These include stability margin management, active stall control, and active flow control. For aircraft engines a safety margin, called the stability margin, is designed into the operation of fans and compressors to prevent the inception of stall over the operating range of these components. However, the peak efficiency operating point of a fan or compressor is often very near the component stall line. If the component could be safely operated closer to the point of peak efficiency then it would enable reduced fuel burn. This in turn would result in reduced emissions $\left(\mathrm{CO}_{2}\right)$ and a savings in aircraft fuel costs. Active compressor control technologies are further described below.

Stability Margin Management. A portion of the stability margin designed into the operation of aircraft gas turbine engine compressors is to account for the effects of inlet distortion (non-uniformity of the inlet airflow) caused by aircraft maneuvers or atmospheric disturbances. This added stability margin results in a performance penalty being paid at low distortion operating conditions such as cruise. Engine companies have estimated that being able to actively control the
Table 1. Active Control Sensors

\begin{tabular}{|c|c|}
\hline $\begin{array}{l}\text { Technology } \\
\text { \& Sensed } \\
\text { Parameter(s) }\end{array}$ & Example Feedback Sensor Specifications \\
\hline $\begin{array}{l}\text { Active Inlet } \\
\text { Control } \\
\text { - Inlet Shock } \\
\text { Position }\end{array}$ & $\begin{array}{l}\text { Example specifications [5]: } \\
\text { - Pressure sensor array } \\
\text { - } 37.5 \text { psi nominal operating pressure } \\
\text { - } \pm 0.1 \% \text { accuracy } \\
\text { - } 1500^{\circ} \mathrm{F} \text { environment } \\
\end{array}$ \\
\hline $\begin{array}{l}\text { Stability } \\
\text { Margin } \\
\text { Management } \\
\text { - Inlet } \\
\quad \text { Distortion }\end{array}$ & $\begin{array}{l}\text { Example specifications [7]: } \\
\text { - } \text { Array of inlet static pressure sensors } \\
\text { - } 0-25 \text { psi range } \\
\text { - } \pm 0.25 \% \text { accuracy } \\
\text { - } 500 \mathrm{~Hz} \text { bandwidth } \\
\text { - } \quad-65 \text { to } 150^{\circ} \mathrm{F} \text { environment } \\
\end{array}$ \\
\hline $\begin{array}{l}\text { Active Stall } \\
\text { Control } \\
\text { - Stall } \\
\text { precursor } \\
\text { phenomena }\end{array}$ & $\begin{array}{l}\text { Example specifications [10]: } \\
\text { - Array of case-mounted static pressure sensors } \\
\text { - } \pm 5 \text { psi dynamic pressure range } \\
\text { - } \pm 0.196 \% \text { accuracy } \\
\text { - } \sim 5 \mathrm{kHz} \text { bandwidth } \\
\text { - } \sim 200^{\circ} \mathrm{F}, \sim 35 \text { psi operating environment }\end{array}$ \\
\hline $\begin{array}{l}\text { Active Flow } \\
\text { Control } \\
\text { - Flow } \\
\text { Separation }\end{array}$ & $\begin{array}{l}\text { Example specifications [11]: } \\
\text { - Two static pressure taps at distributed chord } \\
\text { locations across the flow control vane. } \\
\text { - } \pm 5 \text { psi dynamic pressure range } \\
\text { - } \sim \pm 0.5 \% \text { accuracy } \\
\text { - } \sim 1 \mathrm{~Hz} \text { bandwidth } \\
\text { - } \sim 200^{\circ} \mathrm{F}, \sim 35 \text { psi operating environment } \\
\text { - } \text {-or- } \\
\text { (See mounted static pressure measurements } \\
\text { (See Active Stall Control specs above) }\end{array}$ \\
\hline $\begin{array}{l}\text { Combustion } \\
\text { Instability } \\
\text { Control } \\
\text { - Thermo- } \\
\text { acoustic } \\
\text { instabilities } \\
\end{array}$ & $\begin{array}{l}\text { Example specifications[15]: } \\
\bullet \sim \pm 1 \text { psi dynamic pressure measurements } \\
\bullet \sim 700 \mathrm{~Hz} \text { bandwidth } \\
\bullet \pm 5 \% \text { accuracy } \\
\bullet+2800^{\circ} \mathrm{F},+400 \text { psi combustor environment }\end{array}$ \\
\hline $\begin{array}{l}\text { Emissions } \\
\text { Minimizing } \\
\text { Control } \\
\text { - Combustion } \\
\quad \text { emissions }\end{array}$ & $\begin{array}{l}\text { Example specifications [15]: } \\
\left.\text { - Array of emissions species (CO, } \mathrm{CO}_{2}, \mathrm{NO}\right) \\
\text { measurements at the HPT stator vanes } \\
\text { - } \sim 2500^{\circ} \mathrm{F} \text { environment } \\
\text { - } \pm 5 \% \text { accuracy } \\
\text { - }<5 \mathrm{~Hz} \text { bandwidth } \\
\text { - Dynamic pressure measurements (see } \\
\text { Combustion Instability Control specs above) }\end{array}$ \\
\hline $\begin{array}{l}\text { Burner Pattern } \\
\text { Factor Control } \\
\text { - Burner } \\
\text { Pattern } \\
\text { Factor }\end{array}$ & $\begin{array}{l}\text { Example specifications [15]: } \\
\text { - Circumferential array of temperature } \\
\text { measurements mounted at HPT stator vanes } \\
\text { - } \sim 2500^{\circ} \text { F environment } \\
\text { - } \pm 2 \% \text { accuracy } \\
\text { - }<1 \mathrm{~Hz} \text { bandwidth } \\
\end{array}$ \\
\hline $\begin{array}{l}\text { Active Turbine } \\
\text { Clearance } \\
\text { Control } \\
\text { - Blade to case } \\
\text { Clearance }\end{array}$ & $\begin{array}{l}\text { Example specifications [18]: } \\
\text { - } 0-100 \text { mils range } \\
\text { - } \quad \sim \pm 1 \text { mil accuracy } \\
\text { - } 50 \mathrm{kHz} \text { bandwidth } \\
\text { - } \quad \sim 2500^{\circ} \mathrm{F} \text { HPT environment }\end{array}$ \\
\hline
\end{tabular}

engine so as to safely maintain low stability margins under low distortion operating conditions can result in a reduction of $2 \%$ or more in specific fuel consumption. 
NASA GRC in partnership with Pratt \& Whitney, the U.S. Air Force, McDonnell Douglas Aerospace and NASA Dryden Flight Research Center developed and flight demonstrated technologies to allow for on-line active management of the engine stability margin under the High Stability Engine Control (HISTEC) program [6]. The HISTEC system uses a small number of high-response pressure sensors at the engine face to estimate the type and extent of distortion in real time. This distortion estimate is fed into the control system which adjusts the stability margin accordingly. The characteristics of the sensors used in the HISTEC program [7] are included in Table 1 as an example of distortion estimation sensing options. It should be emphasized that although available sensors were suitable for HISTEC flight test activities, enhancements are necessary in order to develop a less intrusive sensor suitable for installation on a production vehicle. Also, a means to reduce the overall number of sensors required is desirable.

Active Stall Control. Another approach to enhance compressor performance is to extend the stable operating range of the component through active stall control techniques [8]. This will potentially allow the compressor to operate closer to its designed peak efficiency. Active stall control is implemented by sensing dynamic fluid disturbances within the compression system, which are precursor indications to the onset of stall, and activating high bandwidth flow valves located around the circumference of the compressor to counter the flow distortion before it builds up to stall. Challenges for the implementation of active stall control include developing accurate stall phenomenon models for use in control design, developing effective high bandwidth $(\sim 500 \mathrm{~Hz})$ flow control actuators, and developing flight quality high-response sensing capabilities for stall precursor monitoring and feedback control purposes.

Active stall control has been demonstrated in laboratory environments for single and multi-stage compressor designs. These results indicate that substantial extension in the safe operating range of the compressor can be achieved by active stall control technology. Some of the past active stall control sensing options considered/used in these laboratory environments include pressure, mass flow, and temperature measurements [9]. The frequency of the stall precursors of interest is dependent upon the design and operating point of the compressor, but is typically between 10-300 $\mathrm{Hz}$. Measurements must be sampled at a frequency suitably higher to avoid aliasing effects in quantifying the stall precursor phenomena. A circumferential array of sensor measurements is typically employed to assess the spatial harmonics, phase, and rotation frequency of the pre-stall phenomena. For illustration purposes the specifications of the pressure sensors used in the active stall control research described in reference [10] are shown in Table 1. Although these sensors were adequate for research purposes, they are relatively expensive and were found to be somewhat susceptible to failure. Enhancements in the area of sensor technology affordability and robustness are necessary in order to develop sensors suitable for active stall control applications in a production engine. Also, a means to reduce the required number of sensors is desirable.
Active Flow Control. Another representative technology for intelligent engines is active flow control through the use of Smart Vanes [11]. NASA Glenn is currently conducting research in this area in collaboration with Honeywell and Illinois Institute of Technology. This work is being partially funded by the Defense Advanced Research Projects Agency. The goal of Smart Stator Vanes is to provide enabling technology for intelligent engines by diagnosing and eliminating separation on the suction side of stator vanes. These smart vanes are envisioned to be an improvement over the current practice of using variable stator vanes whose angular position is scheduled by the engine controller to ensure component stability over the entire operating envelope. Replacing variable stator vanes with an active flow control approach can reduce weight. While variable stator vanes use a mechanical means to turn the airflow entering a component, smart vanes use an active flow control approach where air is injected into the vane trailing edge to turn the flow. In addition, air blown through holes in the surface of the blade can reduce or eliminate blockage due to separation that can occur on the suction side of the blade. Both steady and unsteady approaches are being investigated. To date, the unsteady blowing shows the most benefit and it requires less flow than steady injection. In a current application, fluidic actuators embedded in the vane are being used to oscillate the flow producing an unsteady boundary condition at the blade surface or trailing edge.

There are a variety of sensing options for measuring flow separation including hot wire and pressure measurements. Reference [11] investigated two feedback sensing options consisting of static pressure taps embedded in the flow control vane and static pressure sensors located in the compressor casing. The sensor parameters associated with this approach are shown in Table 1. In order to develop sensors suitable for active flow control applications in a production engine it is envisioned that enhancements are necessary in the areas of robustness, affordability, and non-intrusive installation capabilities. Furthermore, the capability to service/replace the sensors without requiring a major disassembly of the engine is necessary.

\section{Active Combustion Control}

Future aircraft engines must provide ultra-low emissions and high efficiency at low cost while maintaining the reliability and operability of present day engines. In order to meet these goals advanced combustor designs will be required. Active Combustion Control which consists of feedback-based control of the fuel injection, the fuel-air mixing process, and the staging of fuel sources, can provide an approach to achieving acceptable combustor dynamic behavior while minimizing emissions, and thus can provide flexibility during the combustor design process. Reference [12] provides a review of active combustion control, and discusses current capabilities and future advances required in the related technology areas of control, modeling, actuation, and sensing. The three main areas of interest in active combustion control are: combustion instability control, emission minimizing control, and pattern factor control [13]. The long-term intent is to combine the 
objectives of each individual active combustion control technology into a single intelligent fuel/air management system to provide low emissions throughout the engine operating envelope. These areas are described below and the parameters of interest for feedback control are introduced.

Combustion Instability Control. As the requirements for reducing emissions become more stringent, the combustor designs move towards a "lean" burning solution where the fuel/air mixture contains more air to allow for complete combustion of the fuel while forming less pollutants. However, such combustor designs are more susceptible to instability due to thermo-acoustic driven pressure oscillations. Active control of such oscillations can allow for more efficient, lower emissions combustor designs. In recent years, there has been considerable research into combustion instability suppression. A description of active control of high frequency $(>500 \mathrm{~Hz})$ combustion instability in a combustor rig environment can be found in reference [14]. An example pressure sensing option to detect/quantify combustion instabilities for feedback control is shown in Table 1 [15]. The combustor temperature environment specified in Table 1 is extremely harsh. Developing practical and affordable sensor technology capable of measuring parameters in this environment will be a major challenge. As such, any sensors used for this application may require installation in less harsh "stand-off" locations.

Emission Minimizing Control. In order to simultaneously minimize production of carbon monoxide (CO), unburned hydrocarbons (UHC), and oxides of nitrogen (NOx), tight control over the fuel-air ratio is required throughout the operating range of the combustor. The challenges for this technology are the development of simplified emission production models that can be used for control design, development of suitable approaches to actively control the fuel/air mixture ratio, and the development of the necessary feedback control sensors for operation within the engine environment. It is desirable to have emission species sensors for direct feedback control purposes. A secondary option is to use pressure sensors through which the level of emission production can be inferred. Reference [12] discussed the use of laser diodes, planar laser-induced fluorescence, chemiluminescence, and Fourier Transform Infrared spectrometry as potential emission species measurement options. Example specifications are shown in Table 1. An array of emission measurements taken in close proximity to the combustor exit (such as the second stage HPT stator vane) is desirable as this would allow the performance of individual fuel nozzles to be more accurately assessed. However, the harsh temperature of this environment may require measurements to be taken downstream in less harsh, albeit less preferable, locations.

Burner Pattern Factor Control. Burner Pattern Factor is an indicator of the difference between the maximum and average temperature at the turbine inlet. Reducing the burner pattern factor can eliminate some of the hot streaks at the turbine inlet which will increase the life of turbine blades. Reducing the burner pattern factor may also result in more uniform fuel burning and reduced emissions. Burner Pattern Factor Control seeks to develop an active engine fuel distribution system capable of producing a more uniform combustor exit temperature. Burner Pattern Factor Control frequently employs a temperature feedback approach: based upon temperature feedback from circumferentially arranged temperature sensors at the combustor exit plane, the control system issues commands to fuel flow valves circumferentially arranged inside the combustor so as to achieve as uniform a temperature distribution at the exit plane as possible. Some of the past temperature feedback sensing options considered for burner pattern factor control included an array of thin film thermocouples attached to the high pressure turbine stator vanes [13], and acoustic tomography [16]. Example sensing specifications are shown in Table 1. Developing sensors which can survive in this harsh environment, and which are readily accessible for maintenance purposes are key design issues.

\section{Active Turbine Tip Clearance Control}

Active clearance control aims to improve engine efficiency by manipulating both transient and steady state turbine tip clearances during engine operation $[17,18]$. This can reduce engine operating temperatures resulting in increased on-wing life of engine components. Additional benefits of decreased operating clearances are reductions in emissions and specific fuel consumption. These reductions would result in economic and environmental benefits to the public at large. Conventional approaches employed to optimize clearance include passive designs and open-loop control techniques using fan or compressor bleed air to control the thermal deformation of the case surrounding the turbine. The shortcomings of such techniques are that they do not account for clearance variations due to wear and they are often only optimal at select engine operating points.

Active clearance control provides fast-response clearance control with direct sensor feedback, allowing the full benefits of reduced clearances to be realized over the entire operating profile of the engine. A challenge for active clearance control research is the development of a turbine tip clearance sensor that is highly-reliable and of flight-quality. As the amount of turbine clearance can be asymmetric, it is envisioned that an array of clearance sensors placed circumferentially around the turbine case will be required [18]. Existing turbine tip clearance control systems do not incorporate direct measurement of clearance via sensors. This is due, in part to the inability of existing sensors to meet all of the necessary environmental and operational requirements associated with the turbine. A variety of clearance sensors have been used in laboratory environments including capacitance, eddy current, ultrasonic, and optical sensors. However, none of these sensors are currently used on engines in commercial service. For illustration purposes the required tip clearance sensor characteristics for use in Active Clearance Control Systems as defined in reference [18] are listed in Table 1. 


\section{ADVANCED HEALTH MANAGEMENT TECHNOLOGIES AND SENSOR NEEDS}

Intelligent aircraft engines will require advanced health management capabilities that will accurately assess current engine health and predict remaining engine life. This information, coupled with the engine's projected future use, will enable the optimal scheduling and performance of maintenance. Diagnostics and Prognostics are key elements of an aircraft engine health management system. Diagnostics is the assessment of the current condition of the system and the detection and isolation of any faults. Prognostics predicts remaining system/component life. New information from advanced sensors, algorithms, and life usage monitoring techniques are enabling the advanced health management capabilities envisioned of future intelligent aircraft engines.

For illustration purposes a conceptual engine health management system is shown in Fig. 3. The control process previously shown in Fig. 2 can be seen as a component of this overall architecture. On-board diagnostics and prognostics to assess overall engine health are also included. A propulsion system supervisor coordinates overall PCHM functions. It receives engine command inputs which are fed into the engine control; it transmits engine health information to a vehicle management computer; and, if necessary, it can reconfigure or adapt the engine control based upon the current health of the engine. The vehicle management computer archives and transmits vehicle health and status information to a groundbased fleet information management system. The following sections will discuss health management technologies and the associated sensor needs, specifically in the areas of gas-path performance diagnostics, structural health monitoring, and prognostics.

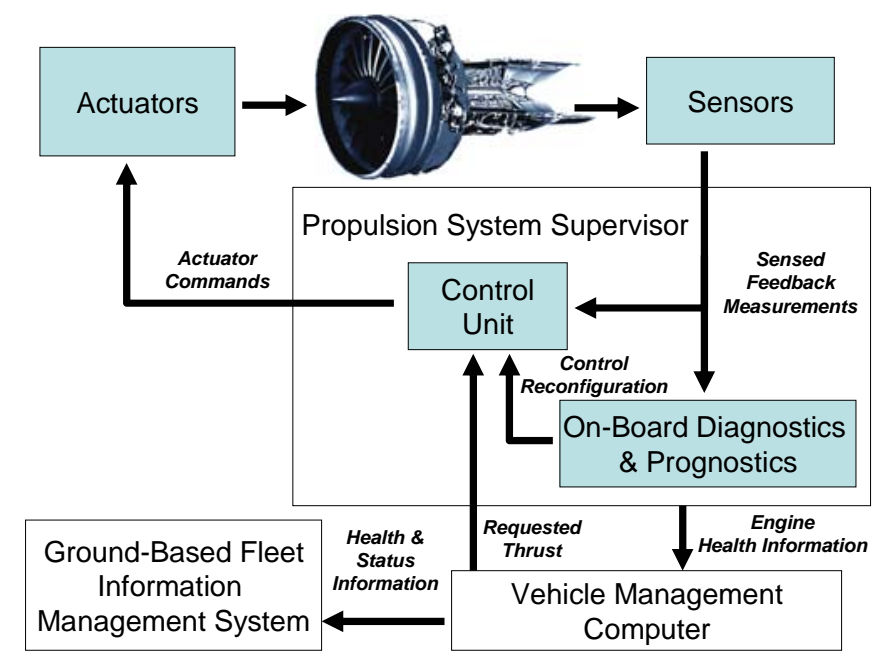

Figure 3. Engine Health Management Architecture

\section{Gas-Path Performance Diagnostics}

Gas-path analysis is the assessment of engine component health through the interpretation of available (control feedback) gas path measurements such as temperatures, pressures, and rotor speeds, and analytical knowledge of the interrelationships between these parameters and component performance. Aircraft operators have used gas-path analysis in ground-based applications for several decades to trend engine performance and diagnose faults [19,20]. More recently, adaptive on-board engine models have been demonstrated for use in real-time engine performance monitoring and optimization of engine control to accommodate off-nominal engine behavior [21,22]. Performance diagnostics and the integration of performance diagnostics with adaptive controls play prominent roles in the intelligent engine vision. Any improvements in the accuracy, uniformity, and reliability of gas path sensors will result in a direct improvement in the accuracy of performance diagnostics and model-based control technologies. Also, there are currently stations within the engine gas-path that are not instrumented due in part to the harsh operating temperatures that exist at these locations. With improvements in high-temperature sensing capabilities, it is expected that sensors will be developed with the capabilities to survive in these environments. Measurements at these additional locations will further enhance the accuracy of gaspath analysis techniques.

In addition to conventional gas path pressure and temperature measurements, the ability to sense additional parameters would be beneficial in diagnosing engine performance faults. For example, gas path debris monitoring sensors $[23,24]$ for monitoring and quantifying engine debris ingestion and discharge are desirable. These sensors employ an electrostatic technique to monitor and quantify the amount of debris present in the engine. When mounted at the engine inlet these sensors would be able to detect the ingestion of foreign objects or debris. Additional debris monitoring sensors mounted near the engine exhaust hold the potential to detect debris generated by wear of turbine blades, abradable rub strips, seals, etc., the liberation of turbine blades/vanes, and variations in combustion by-products. The electrostatic sensor specifications discussed in reference [24] are summarized in Table 2. Cost, weight, size, and reliability of any new gas path sensor designs for flight applications will be key issues. Also, the sensors must be non-intrusive and readily accessible for maintenance purposes.

\section{Structural \& Mechanical Component Health Management}

Conventional aircraft engine health monitoring systems have limited capabilities in the areas of vibration diagnostics and lubrication system monitoring. Typically, relatively low frequency vibration measurements are collected from accelerometers and monitored for exceedance of acceptable vibration magnitudes and rotor-out-of-balance conditions. The onboard signal processing capability to handle high frequency accelerometer measurements is typically not found on today's aircraft. The future vision is to add multiple low-cost high frequency vibration sensors distributed throughout the engine along with the required processors to perform the associated signal processing. This would enable earlier detection and improved isolation of system faults that manifest themselves as a shift in the system vibration signature; (these benefits must of course outweigh the cost of adding any new sensors and/or processors to the engine). Example candidate faults for 
detection via vibration diagnostics include bearing faults, turbine blade failures, gear failures [25], foreign object damage events, disk cracks, and shaft cracks. The vibration frequencies of interest to diagnose such faults are dependent upon the design and rotational speeds of the components of interest. For example, bearing defects (i.e. ball, inner race, and outer race faults) can be diagnosed by monitoring for periodic impacts, which occur at the ball passing frequency, which can be estimated from bearing geometry and rotating speed. Similarly, the vibration signature produced by a disk crack is dependent upon the center of mass displacement and the rotational speed of the part [26,27]. Enhancements are desired to produce affordable flight quality vibration sensors which can be installed inside the engine.

Lubrication system monitoring in today's aircraft engines is often performed post-flight by Spectrographic Oil Analysis Programs [28] which analyze oil samples taken from the engine at specified intervals. Through this process the chemical composition of the oil is analyzed, and checks are made for the presence of contaminants or particles within the oil. Online monitoring capabilities often consist of oil debris monitoring systems such as chip detectors which monitor for the presence of metallic particles in the engine oil system. If fretting or spalling of engine mechanical components occurs, metal particles are generated and released into the system oil. The chip detector sensor contains a magnet to attract any metal particles that may be present in the lubrication system. When a particle becomes attached to the chip detector magnet an electrical circuit is completed and a warning can be generated to have the engine inspected. The future vision is to add multiple low cost oil debris monitoring sensors [29,30,31] throughout the engine lubrication system to provide enhanced fault isolation capability, and the ability to discern particle size and content (ferrous versus non-ferrous particles). The capabilities of the oil debris monitoring sensor described in reference [29] are shown in Table 2 for illustration purposes. Additionally, on-board oil condition monitoring capabilities that provide real-time analytical data on the condition of engine lubricates are envisioned. As an example, parameters to be monitored by an on-line Oil Condition Monitor sensor as described in reference [32] are summarized in Table 2. Affordable flight-quality sensors which are readily installable, and which provide data acquisition from in situ locations throughout the lubrication system are desired.

Some of the advanced structural and mechanical health monitoring sensors under consideration include turbine blade monitoring sensors [33]. Blade monitoring sensors would provide the capability to measure blade tip clearance and blade time of arrival. This in turn could allow the detection of faults such as blade erosion, rubbing, cracking, high cycle fatigue (HCF), and foreign object damage. Some candidate sensing technologies for blade health monitoring include eddy current [34,35], capacitance [36], and optical sensors. In addition to monitoring blade health, these sensors are also promising for use in Active Clearance Control applications (discussed earlier in this paper), disk crack detection, and precise rotor speed measurements. The generic sensor performance requirements for blade health monitoring introduced in reference [34] are
Table 2. Advanced Health Management Sensors

\begin{tabular}{|c|c|}
\hline $\begin{array}{l}\text { Technology } \\
\text { \& Sensed } \\
\text { Parameter(s) }\end{array}$ & $\begin{array}{c}\text { Example Sensor } \\
\text { Specifications/Capabilities }\end{array}$ \\
\hline $\begin{array}{l}\text { Gas Path } \\
\text { Analysis } \\
\text { - Pressures, } \\
\text { Temps, } \\
\text { Rotor speeds }\end{array}$ & $\begin{array}{l}\text { Improvement in conventional sensor accuracy, } \\
\text { sensor-to-sensor uniformity, and reliability; and } \\
\text { new measurements at currently un-instrumented } \\
\text { locations such as the high pressure turbine. }\end{array}$ \\
\hline $\begin{array}{l}\text { Performance } \\
\text { Diagnostics } \\
\text { - Gas Path } \\
\text { Debris }\end{array}$ & $\begin{array}{l}\text { Example specifications [24]: } \\
\text { - Capability to detect debris particles of } 40 \\
\text { microns and larger in size, traveling at the } \\
\text { typical gas turbine engine mass flow velocities } \\
\text { - Inlet }\left(\sim-60 \text { to } 150^{\circ} \mathrm{F}\right) \text { and turbine exit }(\sim 1100 \\
\left.{ }^{\circ} \mathrm{F}\right) \text { operating environments }\end{array}$ \\
\hline $\begin{array}{l}\text { Structural } \\
\text { Health } \\
\text { Monitoring } \\
\text { - Vibration }\end{array}$ & $\begin{array}{l}\text { Example specifications: } \\
\text { - Multiple low-cost, light weight vibration } \\
\text { sensors located throughout the engine to } \\
\text { monitor the features of interest } \\
\text { - } \quad \text { Bandwidths up to } 50 \mathrm{kHz}\end{array}$ \\
\hline $\begin{array}{l}\text { Structural } \\
\text { Health } \\
\text { Monitoring } \\
\text { - Oil debris }\end{array}$ & $\begin{array}{l}\text { Example specifications [29]: } \\
\text { - Capability to detect magnetic and non- } \\
\text { magnetic debris } \\
\text { - Ability to count in excess of } 100,000 \text { particles } \\
\text { ranging in size from } 125 \text { to } 700 \text { microns }\end{array}$ \\
\hline $\begin{array}{l}\text { Structural } \\
\text { Health } \\
\text { Monitoring } \\
\text { - Oil quality }\end{array}$ & $\begin{array}{l}\text { Example sensors [32]: } \\
\text { - } \text { Real-time measurements of engine oil } \\
\text { condition parameters including additive } \\
\text { concentration, water content, fuel dilution, and } \\
\text { concentration of thermal and oxidative } \\
\text { degradation products }\end{array}$ \\
\hline $\begin{array}{l}\text { Structural } \\
\text { Health } \\
\text { Monitoring } \\
\text { - Blade health }\end{array}$ & $\begin{array}{l}\text { Example specifications [34]: } \\
\text { - Standoff distance of 50-300 mils (stage } \\
\text { dependent) } \\
\text { - } \quad \text { Circumferential accuracy of } \pm 2 \text { mils } \\
\text { - Tip clearance accuracy of } 1-5 \text { mils (higher } \\
\text { resolution required as clearance is reduced) } \\
\text { - Temperature environment is stage dependent - } \\
\text { - } \text { up to } 2500^{\circ} \mathrm{F} \text { in turbine stages } \\
\text { - } \text { blade tip speed } \\
\text { - Vibration environment up to } 300 \text { g’s peak }\end{array}$ \\
\hline $\begin{array}{l}\text { Prognostics and } \\
\text { Life Usage } \\
\text { Monitoring } \\
\text { - Component } \\
\quad \text { life usage } \\
\text { parameters }\end{array}$ & $\begin{array}{l}\text { Example sensors: } \\
\text { - Component metal temperatures (up to } \sim 2000^{\circ} \\
\text { F in turbine section), Relatively low } \\
\text { bandwidth }(<5 \mathrm{~Hz}) \\
\text { - Component stress and strain measurements or } \\
\text { inference from other measurements }\end{array}$ \\
\hline $\begin{array}{l}\text { Prognostics and } \\
\text { Life Usage } \\
\text { Monitoring } \\
\text { - NDE } \\
\text { parameters }\end{array}$ & $\begin{array}{l}\text { Example sensors: } \\
\text { - Acoustic emission, ultrasonic systems, } \\
\text { piezoelectric patch, and wireless eddy current } \\
\text { sensors }\end{array}$ \\
\hline
\end{tabular}

summarized in Table 2. In order to be practical for production engine applications, these sensors need to be affordable, reliable, light-weight, and be readily installable and accessible.

\section{Prognostics and Life Usage Monitoring}

Reliable prognostics and life usage monitoring are key enabling technologies for intelligent aircraft engines. 
Prognostics [37] provides early detection of incipient ("very small”) fault conditions within a component, and the capability to manage and predict the progression of this fault condition to component failure. Prognostics is closely related to life usage monitoring which predicts remaining component life based upon the past operating history of the system. Collectively, reliable prognostics, diagnostics, and life usage monitoring capabilities will enable the transition from today's practice of performing aircraft engine maintenance predominately on a time-based schedule, to scheduling and performance of maintenance based upon the condition of the engine. This has the potential to lead to enhanced safety, reduced maintenance related delays and cancellations, less unnecessary maintenance, less unscheduled maintenance, reduced manual effort required to perform maintenance, and increased on-wing life of components. Conventional prognostic/life usage monitoring capabilities are limited but do include trending of component effective cycle counts [38] and trending remaining engine operability margins such as exhaust gas temperature margin. Future enhancements are necessary in the areas of life modeling, fault propagation modeling, and sensors to enable condition-based maintenance. Reference [39] describes a probabilistic approach to engine component life estimation using conventionally available control sensor measurements. The accuracy of such life usage estimation algorithms could be enhanced if additional sensor measurements such as turbine metal temperatures, stress, and strain were available. Example sensors to enhance life usage monitoring are included in Table 2. Sensor designs which can obtain these measurements from stand-off locations are desired.

The Tools for Engine Diagnostics (TED) task under the NASA Aviation Safety Program is working to establish and improve diagnostic and prognostic capabilities for measuring deformation and damage of rotating engine components on the ground and for intermittent or continuous monitoring in the onwing environment [40]. The TED task is investigating a variety of in situ non-destructive evaluation (NDE) techniques to measure and detect very small cracks and incipient fault conditions. This includes the development of vibration-based methodologies for crack detection in rotating disks and shafts. Variations in the system "global" vibration response are monitored to detect crack induced center of mass shifts using non-contact capacitance probes (similar to the sensors and approach discussed in References [27,36]). The identification of disk cracks using "localized" sensors such as acoustic emission, ultrasonic, and piezoelectric patch sensors are also being pursued. Future advances such as slip ring or wireless capabilities are needed to enable in situ implementation of these localized sensors on rotating parts. The TED task is also developing and evaluating a wireless (untethered) eddy current probe for internal engine inspections using readily available borescope access ports. Examples of some of the advanced in situ NDE sensors being developed and/or envisioned for future intelligent aircraft engines prognostics and life usage monitoring are listed in Table 2. Again, advances are necessary in the areas of cost, weight, size, and robustness in order to fabricate sensors suitable for production engine applications.

\section{DISTRIBUTED, FAULT-TOLERANT CONTROL TECHNOLOGIES AND SENSOR NEEDS}

Conventional aircraft engine control architectures consist of a centralized engine control computer with analog interfaces to engine control sensors and actuators. The active component control and advanced health management technologies as envisioned of future intelligent aircraft engines will add additional sensors and actuators to the system. With these added sensors and actuators will come the need for additional wiring harness cabling which can significantly increase the weight and cost of the overall system. An approach to address this issue is to transition from the conventional control architecture, where all of the control, data acquisition, and signal processing logic is housed in a centralized control computer, to a distributed control architecture [41] in which system functionality resides in smart, lightweight, distributed components. Distributed components can be interconnected via a simple communication and power bus, or potentially via a wireless communication architecture, thus significantly reducing the required cabling. Additional benefits include easier troubleshooting and replacement of faulty line replaceable units. A distributed control architecture would require "smart" sensors and actuators which have input signal conditioning, output device driver circuits, self-calibration, processing capabilities, built-in-test (BIT) capabilities, and a communication bus interface. Wireless sensors with power scavenging capabilities are also desirable as they could further reduce required wires and cabling. The necessary miniaturization and packaging would need to be developed for these smart components to be mounted and survive in relatively harsh environments distributed throughout the engine.

\section{UNIVERSAL ENGINE SENSOR REQUIREMENTS}

Any new "intelligent engine" technology under consideration for insertion into next-generation aircraft propulsion systems must be shown to provide tangible benefits over the current state-of-the-art in order to ultimately transition into a product. Issues to be kept in mind specific to any new sensors added to the engine include the fact that these devices often need to be able to tolerate the harsh (high temperature) environment of an aircraft engine with a high degree of reliability [42]. The materials used in conventional sensor designs are not able to survive in some of these environments. Therefore, designs using alternate materials, or innovative standoff or indirect measurement techniques are required. Sensors used for health monitoring purposes need to be more reliable than the fault(s) they are monitoring for, and they must meet any real-time requirements. Otherwise system reliability is compromised instead of enhanced by adding the new technology. Commercial aircraft engine time-before-overhaul durations of 5,000 to 10,000 hours are common, and are expected to increase in the future. Engine sensors will be expected to have similar, if not greater, on-wing lives. In addition to reliability, there are also cost, weight, and size limitations on new technology that can be added to the vehicle. The fabrication, miniaturization, and packaging of any new sensors are thus key issues. Highly-instrumented engines will not be affordable without associated advances in actuation and 
processing capabilities. Smart sensors which integrate local intelligence (i.e. self diagnostic, self-calibrating, and processing capabilities) into the sensor design are envisioned as a means to reduce the size and weight of any added hardware. Sensors which can multiplex multiple measurements into a single signal are also desirable in certain applications. Any sensors installed on the engine must also be readily accessible by maintenance personnel for inspection and/or replacement. Sensors which require either highly-skilled personnel or extensive time/disassembly to service are significantly less desirable as they could cause flight delays and cancellations.

\section{CONCLUSIONS}

This paper reviewed and discussed anticipated sensing needs for future intelligent aircraft engines from a controls and health management perspective. These needs were discussed in the categories of active control, advanced health management, and distributed control - areas which hold much promise for improving the safety, reliability, performance and reducing the emissions and operating costs of aircraft engines. In each of these areas the necessary system features to be sensed were discussed and example sensor specifications were given. In many of these technology areas it was noted that existing sensor technology is being used to support technology maturation in research and laboratory environments. However, significant enhancements are necessary to develop sensors suitable for production engine applications. There are many efforts ongoing to develop advanced controls and health management technologies for aircraft engines. As such it is acknowledged that this paper is not all-encompassing in capturing the sensor needs of all PCHM technologies envisioned or under development. Rather it is a broad overview of the representative sensor needs as presently envisioned to support these technology areas.

\section{REFERENCES}

[1] Garg, S., 2002, "Propulsion Controls and Health Management Research at NASA Glenn Research Center,” NASA TM-2002-211590.

[2] National Aeronautics and Space Administration, 2003, National Aeronautics and Space Administration 2003 Strategic Plan, Washington, DC.

[3] Turbine Engine Technology: A Century of Power for Flight, 2002 IHPTET/VAATE Brochure.

[4] Carlin, C.M., Frisch, I., Kolden, J.J., Koncsek, J.L., Marrs, K.J., Mayer, D.W., McMahon, S.L., Milligan, K.H., Sommerfield, D.M., 2003, "Supersonic Test of the 10-Inch Bifurcated Two-Stage Supersonic Inlet (BTSSI)," NASA/CR-2003-212313.
[5] Hansman, R.J., Kang, B.H., 1988, "Preliminary Definition of Pressure Sensing Requirements for Hypersonic Vehicles,” Paper AIAA-88-4652-CP, AIAA/NASA/AFWAL Conference on Sensors and Measurement Techniques for Aeronautical Applications, Atlanta, GA.

[6] DeLaat, J.C., Southwick, R.D., and Gallops, G.W., 1996, "High Stability Engine Control (HISTEC)," NASA TM 107272, Paper AIAA-96-2586, 32 ${ }^{\text {nd }}$ AIAA/ASME/SAE Joint Propulsion Conference, Lake Buena Vista, FL.

[7] Southwick, R.D., 1999, "High Stability Engine Control (HISTEC): Phase IIIB Final Report,” NASA CR-1999209315.

[8] Weigl, H.J., Paduano, J.D., Fréchette, L.G., Epstein, A.H., Greitzer, E.M., Bright, M.M., Strazisar, A.J., 1998, “Active Stabilization of Rotating Stall and Surge in a Transonic Single Stage Axial Compressor,” ASME Journal of Turbomachinery, 120, No. 4, pp. 625-636.

[9] Simon, J.S., Valavani, L., Epstein, A.H., Greitzer, E.M., 1993, "Evaluation of Approaches to Active Compressor Surge Stabilization,” ASME Journal of Turbomachinery, 115, No. 1, pp. 57-67.

[10] Weigl, H.J., 1997, “Active Stabilization of Rotating Stall and Surge in a Transonic Single Stage Axial Compressor," Doctor of Philosophy Thesis at the Massachusetts Institute of Technology, Cambridge, MA.

[11] Culley, D.E., Bright, M.M., Prahst, P.S., Strazisar, A.J., 2003, “Active Flow Separation Control of a Stator Vane Using Surface Injection in a Multistage Compressor Experiment,” NASA/TM-2003-212356, Paper ASME GT2003-38863, Turbo Expo 2003, Atlanta, GA.

[12] Kiel, B., 2001, "Review of Advances in Combustion Control, Actuation, Sensing, Modeling, and Related Technologies for Air Breathing Gas Turbines,” Paper AIAA A01-16360, 39 ${ }^{\text {th }}$ AIAA Aerospace Sciences Meeting and Exhibit, Reno, NV.

[13] DeLaat, J.C., Breisacher, K.J., Saus, J.R., Paxson, D.E., 2000, “Active Combustion Control for Aircraft Gas Turbine Engines,” NASA/TM-2000-210346, Paper AIAA-20003500, 36th AIAA/ASME/SAE/ASEE Joint Propulsion Conference and Exhibit, Huntsville, AL.

[14] DeLaat, J.C., Chang, C.T., 2003, “Active Control of High Frequency Combustion Instability in Aircraft Gas-Turbine Engines,” NASA/TM-2003-212611, Paper ISABE-20031054, 16th International Symposium on Airbreathing Engines, Cleveland, $\mathrm{OH}$.

[15] Chang, C.T., DeLaat, J.C., 2004, Personal communication.

[16] Kleppe, J.A., Norris, W.J., McPherson, D.R., and Fralik, G.C., 2004, “The Measurement of Performance of Combustors Using Passive Acoustic Methods," $42^{\text {nd }}$ AIAA Aerospace Sciences Meeting and Exhibit, Reno, NV.

[17] Melcher, K.J., Kypuros, J., 2003, “Toward a FastResponse Active Turbine Tip Clearance Control,” Paper ISABE-2003-1102 16th International Symposium on Airbreathing Engines, Cleveland, $\mathrm{OH}$. 
[18] Lattime, S.B., Steinetz, B.M, 2002, “Turbine Clearance Control Systems: Current Practices and Future Directions,” NASA TM-2002-211794.

[19] Urban, L.A., 1972, "Gas Path Analysis Applied to Turbine Engine Condition Monitoring,” Paper AIAA 72-1082, AIAA 8th Joint Propulsion Specialist Conference, New Orleans, LA.

[20] Urban, L.A., and Volponi, A.J., 1992, "Mathematical Methods of Relative Engine Performance Diagnostics,” SAE 1992 Transactions, 101, Journal of Aerospace, Technical Paper 922048.

[21] Luppold, R.H., Roman, J.R., Gallops, G.W., and Kerr, L.J., 1989, "Estimating In-Flight Engine Performance Variations Using Kalman Filter Concepts,” Paper AIAA-892584, AIAA 25th Joint Propulsion Conference, Monterey, CA.

[22] Adibhatla, S., and Johnson, K.L., 1993, "Evaluation of a Nonlinear PSC Algorithm on a Variable Cycle Engine,” Paper AIAA-93-2077, AIAA 29th Joint Propulsion Conference, Monterey, CA.

[23] SAE AIR 4986, 1999, "Engine Electrostatic Gas Path Monitoring."

[24] Powrie, H.E.G., McNicholas, K., 1997, “Gas Path Condition Monitoring During Accelerated Mission Testing of a Demonstrator Engine,” Paper AIAA97-2904, 33 ${ }^{\text {rd }}$ AIAA/ASME/SAE/ASEE Joint Propulsion Conference \& Exhibit, Seattle, WA.

[25] Zakrajsek, J.J., 1989, “An Investigation of Gear Mesh Failure Prediction Techniques,” NASA-TM-102340.

[26] Sonnichsen, H.E., 2000, "Real-time Detection of Developing Cracks in Jet Engine Rotors,” Proc. 2000 IEEE Aerospace Conference, Big Sky, MT, 6, pp. 173-184.

[27] Haase, W.C., Drumm, M.J., 2002, “Detection, Discrimination and Real-Time Tracking of Cracks in Rotating Disks," Proc. of SPIE - The International Society for Optical Engineering, 4704, pp. 139-149.

[28] SAE AIR 1828, 1983, “A Guide to Gas Turbine Engine Oil System Monitoring.”

[29] Taylor, B., 1999, "Real-Time Monitoring of Bearing Condition,” Paper ASME 99-GT-307, International Gas Turbine \& Aeroengine Congress \& Exhibition, Indianapolis, IN.

[30] Miller, J.L., Kitaljevich, D., 2000, “In-Line Oil Debris Monitor for Aircraft Engine Condition Assessment," Proc. 2000 IEEE Aerospace Conference, Big Sky, MT, 6, pp. 1825.

[31] Powrie, H., 1999, "Use of Electrostatic Technology for Aero Engine Oil System Monitoring,” Proc. 1999 IEEE Aerospace Conference, Aspen, CO., 3, pp. 11-20.

[32] Wright, R.L., Pearce, J.A., 2001 "Sensor Technology Improves Jet Engine Reliability,” AFRL Technology Horizons, page 23.

[33] Von Flotow, A., Mercadal, M., Tappert, P., 2000, "Health Monitoring and Prognostics of Blades and Disks with Blade Tip Sensors,” Proc. 2000 IEEE Aerospace Conference, Big Sky, MT, 6, pp. 433-440.
[34] Dowell, M., Sylvester, G., 1999, “Turbomachinery Prognostics and Health Management via Eddy Current Sensing: Current Developments,” Proc. 1999 IEEE Aerospace Conference, Aspen, CO., 3, pp. 1-9.

[35] Roeseler, C., von Flotow, A., Tappert, P., 2002, "Monitoring Blade Passage in Turbomachinery Through the Engine Case (No Holes)," Proc. 2002 IEEE Aerospace Conference, Big Sky, MT., 6, pp. 6-3125 -6-3129.

[36] Drumm, M., Haase, W.C., 2000, "High Performance Rotor Health Monitoring," Proc. of the 19th Digital Avionics Systems Conferences (DASC), Philadelphia, PA, 2, pp. 6E4/1 $-6 \mathrm{E} 4 / 8$.

[37] Engel, S.J., Gilmartin, B.J., Bongort, K., Hess, A., 2000, "Prognostics, the Real Issues Involved With Predicting Life Remaining,” Proc. 2000 IEEE Aerospace Conference, Big Sky, MT, 6, pp. 457-469.

[38] SAE AIR 1872, 1998, "Guide to Life Usage Monitoring and Parts Management for Aircraft Gas Turbine Engines.”

[39] Guo, T.H., Chen, P., 2003, "Sensor Based Engine Life Calculation - A Probabilistic Perspective," NASA/TM2003-212499, Paper ISABE-2003-1147, 16th International Symposium on Airbreathing Engines, Cleveland, $\mathrm{OH}$.

[40] Baaklini, G.Y., Smith, K., Raulerson, D., Gyekenyesi, A.L., Sawicki, J.T., Brasche, L., 2002, “Tools for Engine Diagnostics Under the NASA Aviation Safety Program,” Materials Evaluation, 60, No. 7, pp. 878-883.

[41] Lewis, T.J., 1996, “Distributed Architectures for Advanced Engine Control Systems,” Wright Laboratories, Wright-Patterson AFB, OH USA.

[42] Hunter, G.W., 2003, "Morphing, Self-Repairing Engines: A Vision for the Intelligent Engine of the Future," Paper AIAA 2003-3045, AIAA/ICAS International Air and Space Symposium and Exposition: The Next 100 Years, Dayton, $\mathrm{OH}$. 
Public reporting burden for this collection of information is estimated to average 1 hour per response, including the time for reviewing instructions, searching existing data sources, gathering and maintaining the data needed, and completing and reviewing the collection of information. Send comments regarding this burden estimate or any other aspect of this collection of information, including suggestions for reducing this burden, to Washington Headquarters Services, Directorate for Information Operations and Reports, 1215 Jefferson Davis Highway, Suite 1204, Arlington, VA 22202-4302, and to the Office of Management and Budget, Paperwork Reduction Project (0704-0188), Washington, DC 20503.

\begin{tabular}{|l|l|l|}
\hline 1. AGENCY USE ONLY (Leave blank) & $\begin{array}{c}\text { 2. REPORT DATE } \\
\text { August } 2004\end{array}$ & $\begin{array}{r}\text { 3. REPORT TYPE AND DATES COVERED } \\
\text { Technical Memorandum }\end{array}$ \\
\hline
\end{tabular}

\title{
4. TITLE AND SUBTITLE
} 5. FUNDING NUMBERS

Sensor Needs for Control and Health Management of Intelligent Aircraft Engines

\section{AUTHOR(S)}

Donald L. Simon, Sanjay Garg, Gary W. Hunter, Ten-Huei Guo, and Kenneth J. Semega

\section{PERFORMING ORGANIZATION NAME(S) AND ADDRESS(ES)}

National Aeronautics and Space Administration

John H. Glenn Research Center at Lewis Field

Cleveland, Ohio 44135-3191

\author{
WBS-22-728-30-05
}

1L161102AF20

\section{PERFORMING ORGANIZATION} REPORT NUMBER

\section{E-14711}

\section{SPONSORING/MONITORING AGENCY NAME(S) AND ADDRESS(ES)}

National Aeronautics and Space Administration

Washington, DC 20546-0001

and

U.S. Army Research Laboratory

Adelphi, Maryland 20783-1145

10. SPONSORING/MONITORING AGENCY REPORT NUMBER

NASA TM-2004-213202

ARL-TR-3251

GT2004-54324

\section{SUPPLEMENTARY NOTES}

Prepared for the Turbo Expo 2004 sponsored by the American Society of Mechanical Engineers, Vienna, Austria, June 14-17, 2004. Donald L. Simon, U.S. Army Research Laboratory, NASA Glenn Research Center; Sanjay Garg, Gary W. Hunter, and Ten-Huei Guo, NASA Glenn Research Center; Kenneth J. Semega, Wright-Patterson Air Force Base, Dayton, Ohio 45433. Responsible person, Donald L. Simon, organization code 0300, 216-433-3740.

12a. DISTRIBUTION/AVAILABILITY STATEMENT

\section{2b. DISTRIBUTION CODE}

Unclassified - Unlimited

Subject Category: 07

Distribution: Nonstandard

Available electronically at http://gltrs.grc.nasa.gov

This publication is available from the NASA Center for AeroSpace Information, 301-621-0390.

13. ABSTRACT (Maximum 200 words)

NASA and the U.S. Department of Defense are conducting programs which support the future vision of "intelligent" aircraft engines for enhancing the affordability, performance, operability, safety, and reliability of aircraft propulsion systems. Intelligent engines will have advanced control and health management capabilities enabling these engines to be self-diagnostic, self-prognostic, and adaptive to optimize performance based upon the current condition of the engine or the current mission of the vehicle. Sensors are a critical technology necessary to enable the intelligent engine vision as they are relied upon to accurately collect the data required for engine control and health management. This paper reviews the anticipated sensor requirements to support the future vision of intelligent engines from a control and health management perspective. Propulsion control and health management technologies are discussed in the broad areas of active component controls, propulsion health management and distributed controls. In each of these three areas individual technologies will be described, input parameters necessary for control feedback or health management will be discussed, and sensor performance specifications for measuring these parameters will be summarized.

\section{SUBJECT TERMS}

Aircraft engines; Systems health monitoring; Gas turbine engines; Flight safety 15. NUMBER OF PAGES 16

\begin{tabular}{|c|c|c|}
\hline $\begin{array}{c}\text { 17. SECURITY CLASSIFICATION } \\
\text { OF REPORT }\end{array}$ & $\begin{array}{c}\text { 18. SECURITY CLASSIFICATION } \\
\text { OF THIS PAGE }\end{array}$ & $\begin{array}{c}\text { 19. SECURITY CLASSIFICATION } \\
\text { OF ABSTRACT } \\
\text { Unclassified }\end{array}$ \\
Unclassified & Unclassified
\end{tabular}



